\title{
Laccase-Mediated Enhancement of the Antioxidant Activity of Propolis and Poplar Bud Exudates
}

\author{
Lorenzo Botta, Fabrizio Brunori, Antonia Tulimieri, Davide Piccinino, Roberta Meschini,* \\ and Raffaele Saladino*(0)
}

Department of Biological and Ecological Sciences, University of Tuscia, Via S. Camillo de Lellis snc, I-01100 Viterbo, Italy

\section{Supporting Information}

ABSTRACT: The treatment of propolis and poplar bud exudates with laccase from Trametes versicolor and 2,2,6,6tetramethyl-1-piperidinyloxy free radical increased the antioxidant activity, as evaluated by the $2,2^{\prime}$-diphenyl picrylhydrazyl (DPPH)- and $t$-butyl-OOH-induced DNA breakage comet assay analyses. The effect was highest for shorter reaction times. Propolis showed the highest antioxidant activity in the DPPH test, whereas poplar bud exudates were more active in reducing the $t$-butyl-OOH-induced lesions in the Chinese hamster ovary cell line. Even if the concentration of polyphenols decreased during the oxidation, the formation of

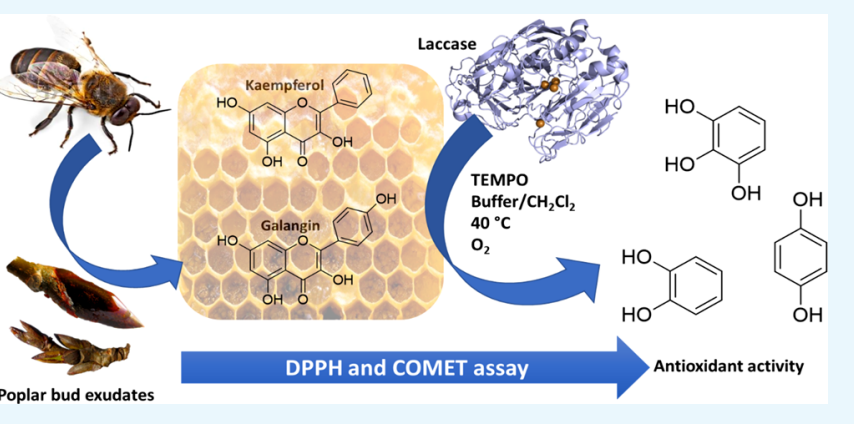
low-molecular-weight phenols phloroglucinol 4 (1,3,5-trihydroxy benzene), hydroquinone 5 (1,4-dihydroxy benzene), and catechol 6 (1,2-dihydroxy benzene), characterized by the radical-scavenging activity, can account for the observed increase in the antioxidant activity.

\section{INTRODUCTION}

Propolis is a dark-colored resinous substance collected by Apis mellifera from various tree buds for the construction and adaptation of nests. ${ }^{1-3}$ The composition of propolis is chemically related to that of bud exudates from which it derives, reflecting the specificity of the local ecological conditions., ${ }^{4,5}$ Propolis and poplar bud exudates show antitumoral, ${ }^{6}$ antibacterial, ${ }^{7}$ anti-inflammatory, ${ }^{8}$ antiviral, ${ }^{9}$ and antioxidant properties. ${ }^{10-14}$ Phenyl propanoid acids and flavonoids (polyphenols) are mainly responsible for the antioxidant activity. ${ }^{15,16}$ The position and stereoelectronic properties of the substituents on the aromatic rings of polyphenols $^{17,18}$ as well as the presence of catechol and pyrogallol pharmacophores tune the antioxidant effect. ${ }^{19-21}$

The main transformations of polyphenols during food processing are catalyzed by phenol oxidases, such as laccases. $^{22,23}$ Laccases (EC 1.10.3.2, para-diphenol, dioxygen oxidoreductase) are multicopper enzymes that catalyze the oxidation of four molecules of substrate through the reduction of dioxygen $\left(\mathrm{O}_{2}\right)$ to water. ${ }^{24}$ They are tolerant to non-natural media (organic solvents and ionic liquids) and resistant to different types of inhibitors. ${ }^{25}$ Examples of the applications of nonaqueous enzymology in the oxidation of polyphenols with laccases have already been reported. ${ }^{26,27}$ The reactivity of laccases $\left(E_{0}=0.5-0.8 \mathrm{~V} \text { vs normal hydrogen electrode }\right)^{28}$ toward high-redox-potential substrates can be increased in the presence of redox mediators in the so-called laccase-mediator systems (LMSs). ${ }^{29}$ Redox mediators, such as 2,2,6,6-tetramethyl-1-piperidinyloxy free radical (TEMPO; $\left.E_{0}=0.75 \mathrm{~V}\right){ }^{30}$ diffuse far away from the active site of the enzyme in the bulk of the solution, increasing the possible biotechnological applications. ${ }^{31}$ TEMPO undergoes a one-electron transfer mechanism to form the oxoammonium ion intermediate. ${ }^{32}$ TEMPO-based LMSs were shown to be the best catalytic systems in the oxidation of different recalcitrant compounds. ${ }^{33}$ LMSs oxidize polyphenols by radical cross-coupling reactions, ${ }^{34}$ oxidative ring-opening reactions, ${ }^{35}$ and aromatic ring hydroxylations. ${ }^{36,37}$ The oxidation of catechins to theaflavins by laccases is recognized as a model for the chemical transformation of green tea into black tea. ${ }^{38}$ Moreover, laccases and vanillin (i.e., a natural redox mediator) act as sensoring systems to analyze poplar hydrolysates. ${ }^{39}$ Preliminary data reported that the oxidation of different propolis (geographical locations and floral origin: Livada, Carei, Cristian, Fagaras, and Gura) with laccase from Sclerotinia sclerotiorum without redox mediators generally leads to the pro-oxidant activity in a complex laccasehemoglobin system. In this latter case, the pro-oxidant activity was not correlated with the redox potential. ${ }^{40} \mathrm{We}$ describe here that the oxidation of propolis and poplar bud exudates with laccase from Trametes versicolor in the presence of TEMPO increased the antioxidant activity for a shorter reaction time, as evaluated by the $2,2^{\prime}$-diphenyl picrylhydrazyl $(\mathrm{DPPH})^{41}$ test and by the $t$-butyl-OOH-induced DNA breakage in the alkaline comet assay. ${ }^{42}$ The antioxidant activity was compared with the oxidation pathway of polyphenols because they are recognized

Received: March 13, 2017

Accepted: May 16, 2017

Published: June 6, 2017 
to be the main factors responsible for the antioxidant activity of propolis and poplar bud exudates. ${ }^{43,44}$

\section{RESULTS AND DISCUSSION}

Commercially available black bud poplar exudate (Populus nigra) and propolis (from China) were extracted with $\mathrm{MeOH}$ $(80 \% \mathrm{v} / \mathrm{v}$ water) to afford PN-A and PROP samples, respectively. The extraction of the black bud poplar exudate was also performed with EtOH ( $80 \% \mathrm{v} / \mathrm{v}$ water) to afford $\mathrm{PN}$ B. The samples were preliminarily characterized by gas chromatography-mass spectrometry (GC-MS) after treatment with $\mathrm{N}, \mathrm{O}$-bis-trimethylsilyl trifluoroacetamide (NBSA) in the presence of oleic acid as internal standard. The GC profiles of PROP, PN-A, and PN-B samples are in Supporting Information SI \#1 (Figures SI1A-C). To identify the chemical structure of polyphenols, two strategies were followed. First, the spectra of identifiable peaks were compared with commercially available mass spectrum libraries, such as NIST (Fison, Manchester, U.K.). In contrast, the GC-MS analyses were repeated using commercially available standard compounds (method of addition). Tables $1-3$ report the most abundant polyphenols detected in the samples [mass-to-charge ratio $(\mathrm{m} / z)$ values and the abundance of peaks of identified polyphenols are in Table SI2A; mass-to-charge ratio fragmentation spectra of identified polyphenols are in SI \#3]. We identified a large panel of compounds, including (a) phenol derivatives: 2-hydroxybenzyl alcohol, salicylic acid, and vanillin; (b) phenyl propanoid derivatives: cinnamyl alcohol, cinnamic acid, 4-hydroxy cinnamic acid, 4-hydroxy cinnamic acid methyl ester, 3,4-dimethoxy cinnamic acid, ferulic acid, caffeic acid, and caffeic acid phenethyl ester; (c) flavanons: pinostrobin, naringenin, and sakuranetin; (d) diidro flavonols: pinobanksin and 3-O-acetyl pinobanksin; (e) flavons: chrysin, tectochrysin, and genkwanin; and (f) flavanols: galangin, kaempferol, isorhamnetin, and quercetin (only in the case of PN-A and PN-B samples). The structures of the identified polyphenols are presented in SI \#4.

The oxidation of PROP, PN-A, and PN-B samples was performed with laccase from $T$. versicolor, ${ }^{45}$ in the presence of TEMPO. ${ }^{46-51}$ Laccase from $T$. versicolor showed the optimal $\mathrm{pH}$ value of 5.5 and the following kinetic parameters: $K_{\mathrm{m}}=1.6$ $\mathrm{mM}, V_{\max }=1381 \times 10^{-3} \Delta \mathrm{Abs}\left(\min \mu \mathrm{g}_{\text {enzyme }}\right)^{-1}, V_{\max } / K_{\mathrm{m}}=$ 8752 (average errors in the kinetic parameters were $\pm 2-4 \%$ for $K_{\mathrm{m}}$ and $\pm 1-3 \%$ for $\left.V_{\max }\right)$. Briefly, the appropriate sample $(0.1$ $\mathrm{g})$ was treated with laccase $(10 \mathrm{U})$ and TEMPO $(6 \mathrm{mM})$ in 0.1 $\mathrm{M}$ sodium acetate buffer $(3.0 \mathrm{~mL}, \mathrm{pH} 5-5.5)$ at $40{ }^{\circ} \mathrm{C}$, in the presence of a low amount of $\left.\mathrm{CH}_{2} \mathrm{Cl}_{2}(5.0 \% \mathrm{v} / \mathrm{v})\right)^{31}$ Nonaqueous enzymology shows numerous advantages with respect to traditional conditions, such as increased solubility of substrates, improved stability and selectivity, and limited side reactions. ${ }^{52}$ The reaction mixtures were vigorously stirred at room temperature, quenched after 1,7 , and $15 \mathrm{~h}$, and analyzed by GC-MS. The GC profiles at $1 \mathrm{~h}$ are reported in Supporting Information SI \#1 (Figures SI \#1D-SI \#1F). The reaction mixtures quenched at $7 \mathrm{~h}$ were also purified by highperformance liquid chromatography (HPLC, as selected samples) to isolate possible degradation products. Tables $1-3$ report the composition of polyphenols in the reaction mixtures (columns 4-6). Figure 1 depicts the pattern of different types of polyphenols at different reaction times.

Regardless of the experimental conditions, polyphenols decreased continuously during the oxidation process, reaching ca. $50 \%$ of the initial concentration at $15 \mathrm{~h}$. The PN-A sample
Table 1. Composition of the Most Abundant Polyphenols in the PN-A Sample before and after Treatment with Laccase from T. versicolor and TEMPO ${ }^{a}$

\begin{tabular}{|c|c|c|c|c|c|}
\hline & & $\begin{array}{l}\text { starting } \\
\text { material }\end{array}$ & $t=1 \mathrm{~h}$ & $t=7 \mathrm{~h}$ & $t=15 \mathrm{~h}$ \\
\hline type & compound & & yield & $\mathrm{ng} / \mathrm{g})^{b}$ & \\
\hline phenols & hydroquinone & n.d. & 8.83 & 6.35 & 3.75 \\
\hline & catechol & n.d. & 0.41 & 0.19 & 0.05 \\
\hline & phloroglucinol & n.d. & 0.18 & 0.07 & 0.03 \\
\hline & $\begin{array}{l}\text { 2-hydroxybenzyl } \\
\text { alcohol }\end{array}$ & 0.01 & 0.01 & 0.01 & 0.005 \\
\hline & salicylic acid & 0.94 & 0.60 & 0.54 & 0.35 \\
\hline & vanillin & 0.16 & 0.14 & 0.03 & 0.01 \\
\hline phenyl & cinnamyl alcohol & 0.51 & 0.25 & 0.29 & 0.11 \\
\hline & cinnamic acid & 9.40 & 4.33 & 4.95 & 2.11 \\
\hline & $\begin{array}{l}\text { 4-hydroxy } \\
\text { cinnamic acid }\end{array}$ & 1.53 & 1.51 & 1.47 & 1.22 \\
\hline & $\begin{array}{l}\text { 4-hydroxy } \\
\text { cinnamic acid } \\
\mathrm{ME}^{c}\end{array}$ & 2.87 & 0.93 & 0.87 & 0.32 \\
\hline & $\begin{array}{l}\text { 3,4-dimethoxy } \\
\text { cinnamic acid }\end{array}$ & 4.63 & 6.66 & 2.46 & 1.11 \\
\hline & ferulic acid & 7.12 & 1.38 & 1.36 & 1.28 \\
\hline & caffeic acid & 9.20 & 9.83 & 1.01 & 0.81 \\
\hline & caffeic acid $\mathrm{PE}^{d}$ & 10.24 & 10.67 & 10.24 & 8.10 \\
\hline flavanones & pinostrobin & 8.43 & 4.99 & 4.71 & 4.65 \\
\hline & naringenin & 16.63 & 7.93 & 7.52 & 3.32 \\
\hline & sakuranetin & 5.23 & 4.81 & 4.75 & 4.13 \\
\hline dihydro & pinobanksin & 17.85 & 11.81 & 9.53 & 8.44 \\
\hline & $\begin{array}{l}\text { 3-O-acetyl } \\
\text { pinobanksin }\end{array}$ & 9.4 & 6.27 & 5.10 & 2.50 \\
\hline flavones & chrysin & 16.03 & 13.94 & 13.23 & 13.81 \\
\hline & tectochrysin & 4.35 & 5.84 & 5.67 & 3.71 \\
\hline flavonols and & galangin & 2.55 & 1.74 & 0.39 & 0.09 \\
\hline $\begin{array}{l}\text { flavonol } \\
\text { derivatives }\end{array}$ & kaempferol & 2.50 & 1.13 & 0.27 & 0.07 \\
\hline & isorhamnetin & 3.12 & 2.17 & 2.14 & 2.0 \\
\hline & quercetin & 0.63 & 0.50 & 0.40 & 0.12 \\
\hline & compound $\mathbf{1}^{e}$ & n.d. & n.d. & 1.18 & n.d. \\
\hline & compound 2 & n.d. & n.d. & 0.16 & n.d. \\
\hline & compound 3 & n.d. & n.d. & 1.02 & n.d. \\
\hline
\end{tabular}

${ }^{a}$ The oxidations were performed by treating the appropriate sample $(0.1 \mathrm{~g})$ with laccase $(10 \mathrm{U})$ and TEMPO $(6 \mathrm{mM})$ in $0.1 \mathrm{M}$ sodium acetate buffer $(3.0 \mathrm{~mL}, \mathrm{pH} 5-5.5)$ at $40{ }^{\circ} \mathrm{C}$, in the presence of a low amount of $\mathrm{CH}_{2} \mathrm{Cl}_{2}(5.0 \% \mathrm{v} / \mathrm{v}) .{ }^{b}$ The yield was reported as milligrams of compound per gram of starting material. ${ }^{c} \mathrm{ME}$ : methyl ester. ${ }^{d} \mathrm{PE}$ : Phenethyl ester. ${ }^{e}$ Compound 1: 2-(4-hydroxybenzoyl)-2,4,6-trihydroxy-3(2H)-benzofuranone; compound 2: 2-(3,4-dihydroxybenzoyl)-2,4,6-trihydroxy-3(2H)-benzofuranone; compound 3: galangin dimer.

showed a higher depletion of polyphenols than the PN-B sample (Figure 1) probably due to the presence of an appreciable amount of vanillin, which is a natural redox mediator for laccase. ${ }^{53}$ The general order of the reactivity of flavonoids observed in all samples was: flavonols > flavanones, dihydro flavonols > flavones (very low reactivity). Phenyl propanoid derivatives were all efficiently oxidized by laccase (Tables 1-3, Figure 1).

The high reactivity of flavonols was in accordance with the data previously reported for the oxidation of purified flavonoids with laccase from $T$. versicolor. This latter study highlighted the important role played by the hydroxy group at C3 of the chromene ring in the first step of the reaction. The mechanism requires the initial $\mathrm{H}$ abstraction from $\mathrm{C} 3-\mathrm{OH}$ followed by the 
Table 2. Composition of the Most Abundant Polyphenols in the PN-B Sample before and after Treatment with Laccase from $T$. versicolor and TEMPO ${ }^{a}$

\begin{tabular}{|c|c|c|c|c|c|}
\hline & & $\begin{array}{l}\text { starting } \\
\text { material }\end{array}$ & $t=1 \mathrm{~h}$ & $t=7 \mathrm{~h}$ & $t=15 \mathrm{~h}$ \\
\hline type & compound & & yield & $\mathrm{ng} / \mathrm{g})^{b}$ & \\
\hline phenols & hydroquinone & n.d. & 8.04 & 7.47 & 4.51 \\
\hline & catechol & n.d. & 0.89 & 0.32 & 0.15 \\
\hline & phloroglucinol & n.d. & 0.23 & 0.09 & 0.13 \\
\hline $\begin{array}{l}\text { phenyl } \\
\text { propanoids }\end{array}$ & $\begin{array}{r}\text { cinnamyl } \\
\text { alcohol }\end{array}$ & 0.14 & 0.03 & 0.02 & 0.01 \\
\hline & cinnamic acid & 0.12 & 0.38 & 0.12 & 0.04 \\
\hline & $\begin{array}{l}\text { 3,4-dimethoxy } \\
\text { cinnamic acid }\end{array}$ & 0.13 & 0.23 & 0.07 & 0.02 \\
\hline & ferulic acid & 0.25 & 0.04 & 0.03 & 0.03 \\
\hline & caffeic acid & 1.17 & 1.26 & 1.03 & 0.54 \\
\hline & caffeic acid $\mathrm{PE}^{c}$ & 8.75 & 1.72 & 0.57 & 0.46 \\
\hline flavanons & pinostrobin & 23.22 & 10.75 & 8.73 & 8.06 \\
\hline & sakuranetin & 2.30 & 1.69 & 1.64 & 0.84 \\
\hline dihydro flavonols & pinobanksin & 33.06 & 18.27 & 13.39 & 11.85 \\
\hline & $\begin{array}{l}\text { 3-O-acetyl } \\
\text { pinobanksin }\end{array}$ & 5.75 & 2.06 & 2.01 & 0.76 \\
\hline flavons & chrysin & 3.77 & 2.97 & 2.51 & 2.12 \\
\hline & tectochrysin & 27.67 & 30.74 & 30.59 & 26.65 \\
\hline flavonols and & galangin & 42.11 & 34.25 & 23.31 & 19.27 \\
\hline derivatives & kaempferol & 6.97 & 5.72 & 4.47 & 2.68 \\
\hline & quercetin & 1.81 & 1.12 & 0.71 & 0.18 \\
\hline & compound $\mathbf{1}^{d}$ & n.d. & n.d. & 1.80 & n.d. \\
\hline & compound 2 & n.d. & n.d. & 0.75 & n.d. \\
\hline & compound 3 & n.d. & n.d. & 8.02 & n.d. \\
\hline
\end{tabular}

$a_{\text {The oxidations were performed by treating the appropriate sample }}$ $(0.1 \mathrm{~g})$ with laccase $(10 \mathrm{U})$ and TEMPO $(6 \mathrm{mM})$ in $0.1 \mathrm{M}$ sodium acetate buffer $(3.0 \mathrm{~mL}, \mathrm{pH} 5-5.5)$ at $40{ }^{\circ} \mathrm{C}$, in the presence of a low amount of $\mathrm{CH}_{2} \mathrm{Cl}_{2}(5.0 \% \mathrm{v} / \mathrm{v}) .{ }^{b}$ The yield was reported as milligrams of compound per gram of starting material. ${ }^{c} \mathrm{PE}$ : phenethyl ester. ${ }^{d}$ Compound 1: 2-(4-hydroxybenzoyl)-2,4,6-trihydroxy-3(2H)-benzofuranone; compound 2: 2-(3,4-dihydroxybenzoyl)-2,4,6-trihydroxy$3(2 \mathrm{H})$-benzofuranone; compound 3: galangin dimer.

formation of a carbocation at C-2 (by dismutation reaction between two radicals), nucleophilic addition, and rearrangement of the C-ring (see Figure 2 for the nomenclature of the aromatic rings in flavonols). ${ }^{54}$ The occurrence of this oxidative pathway was confirmed by the detection of 2-(4-hydroxybenzoyl)-2,4,6-trihydroxy-3(2H)-benzofuranone 1, 2-(3,4-dihydroxybenzoyl)-2,4,6-trihydroxy-3 $(2 H)$-benzofuranone 2 , and the galangin dimer 3 in the reaction mixtures quenched at 7 $\mathrm{h}$ after HPLC purification (at a selected reaction time) (Scheme 1). ${ }^{54}$ Compounds $\mathbf{1}$ and $\mathbf{2}$ were produced by the addition of water to the respective $\mathrm{C} 2$ carbocation intermediates, followed by the C-ring rearrangement, whereas compound 3 was derived from the addition of a second molecule of galangin on the first formed C2 galangin carbocation. ${ }^{54-58}$ Under similar experimental conditions, flavones were found to be stable, thereby highlighting the crucial role of the $\mathrm{C} 3-\mathrm{OH}$ group in the oxidation of flavonoids with laccase. ${ }^{59}$

Simple low-molecular-weight phenols phloroglucinol 4, hydroquinone 5 , and catechol 6 were also detected in appreciable amounts by GC-MS analyses (Tables $1-3$, Figure 1 , and Scheme 1). Phloroglucinol (1,3,5-trihydroxy benzene) is usually produced during the degradation of the A-ring of kaempferol and naringenin by oxidative metabolism. ${ }^{60,61}$
Table 3. Composition of the Most Abundant Polyphenols in the PROP Sample before and after Treatment with Laccase from $T$. versicolor and TEMPO $^{a}$

\begin{tabular}{|c|c|c|c|c|c|}
\hline & & $\begin{array}{l}\text { starting } \\
\text { material }\end{array}$ & $t=1 \mathrm{~h}$ & $t=7 \mathrm{~h}$ & $t=15 \mathrm{~h}$ \\
\hline type & compound & & $\overline{\text { yield }}$ & $\mathrm{ng} / \mathrm{g})^{b}$ & \\
\hline phenols & hydroquinone & n.d. & 8.83 & 5.35 & 2.15 \\
\hline & catechol & n.d. & 0.37 & 0.12 & 0.03 \\
\hline & phloroglucinol & n.d. & 0.14 & 0.07 & 0.01 \\
\hline phenyl & cinnamyl alchol & 4.56 & 5.17 & 2.55 & 2.98 \\
\hline propanoids & cinnamic acid & 2.37 & 2.96 & 1.87 & 1.80 \\
\hline & $\begin{array}{l}\text { 4-hydrocinnamic } \\
\text { acid }\end{array}$ & 0.40 & 0.20 & 0.13 & 0.14 \\
\hline & $\begin{array}{l}\text { 3,4-dimethoxy } \\
\text { cinnamic acid }\end{array}$ & 1.91 & 2.30 & 1.17 & 1.47 \\
\hline & $\begin{array}{l}\text { 4-hydroxy } \\
\text { cinnamic acid } \\
\mathrm{ME}^{c}\end{array}$ & 1.12 & 1.62 & 1.67 & 1.58 \\
\hline & caffeic acid & 1.34 & 1.14 & 0.98 & 0.31 \\
\hline & caffeic acid $\mathrm{PE}^{d}$ & 18.23 & 10.85 & 7.29 & 7.18 \\
\hline & ferulic acid & 9.25 & 2.59 & 2.34 & 2.13 \\
\hline flavanones & pinostrobin & 4.30 & 3.26 & 2.95 & 2.30 \\
\hline & naringenin & 0.25 & 0.13 & 0.11 & 0.08 \\
\hline & sakuranetin & 0.17 & 0.14 & 0.08 & 0.10 \\
\hline dihydro & pinobanksin & 3.32 & 2.68 & 2.70 & 1.82 \\
\hline & $\begin{array}{l}\text { 3-O-acetyl } \\
\text { pinobanksin }\end{array}$ & 0.03 & 0.02 & 0.01 & n.d. \\
\hline flavones & chrysin & 35.57 & 33.25 & 29.36 & 17.96 \\
\hline & tectochrysin & 2.58 & 3.42 & 3.11 & 2.12 \\
\hline & genkwanin & 1.48 & 1.34 & 1.27 & 1.11 \\
\hline flavonols and & galangin & 13.23 & 10.84 & 7.12 & 6.68 \\
\hline flavonol & kaempferol & 0.19 & 0.09 & 0.08 & 0.04 \\
\hline & isorhamnetin & 3.33 & 2.47 & 0.46 & traces \\
\hline & compound $\mathbf{1}^{e}$ & n.d. & n.d. & 0.05 & n.d. \\
\hline & compound 3 & n.d. & n.d. & 5.32 & n.d. \\
\hline
\end{tabular}

${ }^{a_{T}}$ The oxidations were performed by treating the appropriate sample $(0.1 \mathrm{~g})$ with laccase $(10 \mathrm{U})$ and TEMPO $(6 \mathrm{mM})$ in $0.1 \mathrm{M}$ sodium acetate buffer $(3.0 \mathrm{~mL}, \mathrm{pH} 5-5.5)$ at $40{ }^{\circ} \mathrm{C}$, in the presence of a low amount of $\mathrm{CH}_{2} \mathrm{Cl}_{2}(5.0 \% \mathrm{v} / \mathrm{v}) .{ }^{b}$ The yield was reported as milligrams of compound per gram of starting material. ${ }^{c} \mathrm{ME}$ : methyl ester. ${ }^{d} \mathrm{PE}$ : phenethyl ester. ${ }^{e}$ Compound 1: 2-(4-hydroxybenzoyl)-2,4,6-trihydroxy-3 $2 \mathrm{H})$-benzofuranone; compound 3: galangin dimer.

Moreover, 2,4,6-trihydroxy benzoic acid, which is a chemical precursor of phloroglucinol by decarboxylation, was obtained by the treatment of quercetin with the peroxyl-radicalgenerating agent, azobisisobutyronitrile. ${ }^{55}$ Hydroquinone (1,4dihydroxy benzene) and catechol (1,2-dihydroxy benzene) have been observed during the oxidation of flavonoids and other complex phenols. $^{62}$ The concentration of compounds 4-6 was highest at $7 \mathrm{~h}$ of the oxidation (Figure 1).

The antioxidant activities of the PROP, PN-A, and PN-B samples before and after the treatment with laccase were initially evaluated by the DPPH radical-scavenging analysis. ${ }^{63}$ Briefly, the appropriate sample was dissolved in EtOH (0.01$100 \mathrm{mg} / \mathrm{mL}$ ) and added to a freshly prepared DPPH solution $\left(6 \times 10^{-5} \mathrm{M}\right.$ in EtOH $)$. The decrease in absorbance $(475 \mathrm{~nm})$ was determined at different times until the reaction reached a plateau. The kinetics of the process was analyzed for each concentration tested, and the DPPH activity remaining at the steady state was estimated. This value was used to calculate $\mathrm{IC}_{50}$ (i.e., the concentration of substrate in milligrams per milliliter that causes $50 \%$ loss of the DPPH activity). ${ }^{64}$ PROP showed an $\mathrm{IC}_{50}$ value $(110 \mu \mathrm{g} / \mathrm{mL})$ of the same order of magnitude as 

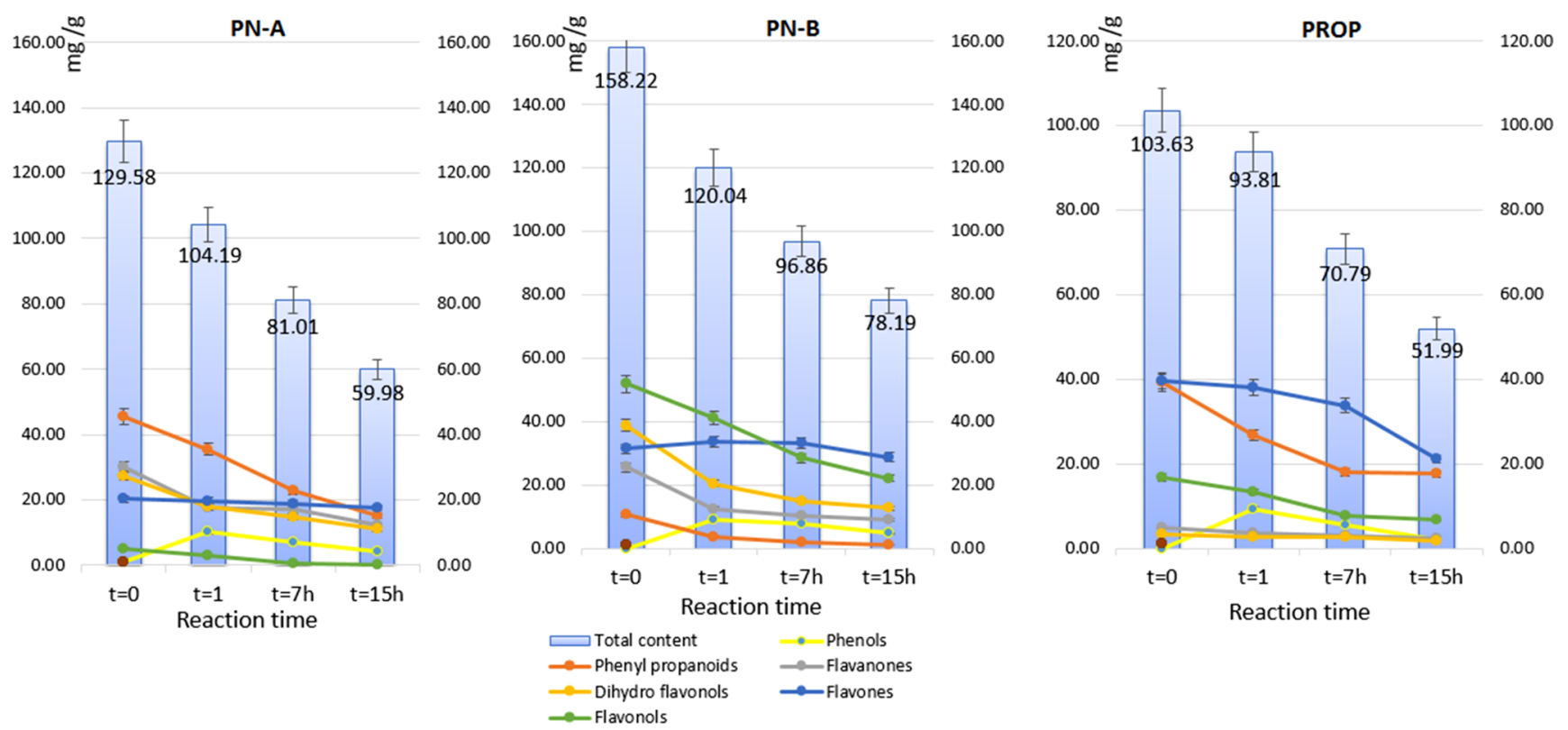

Figure 1. Variation of the concentration of polyphenols $(\mathrm{mg} / \mathrm{g})$ with the reaction time $(\mathrm{h})$ in the oxidation of PROP, PN-A, and PN-B samples with T. versicolor and TEMPO.

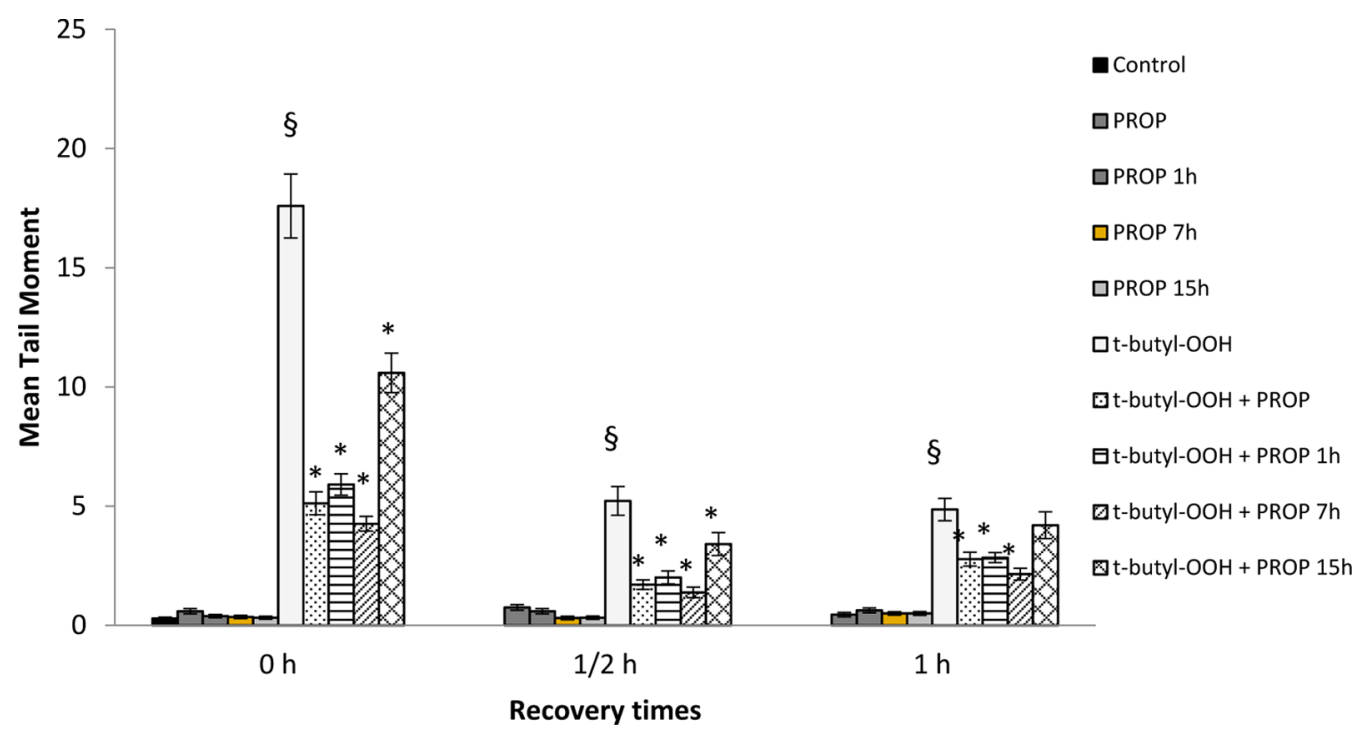

Figure 2. Mean tail moment (TM) values obtained at different recovery times for both control and $t$-butyl-OOH-treated samples with and without pretreatment with PROP. Student's $t$-test, $\S t$-butyl-OOH vs control, $p<0.01$; * Propolis 1 , 7 , and 15 h vs $t$-butyl-OOH, $p<0.01$.

Brazilian, Korean, and Australian red propolis (Table 4, entry 1). ${ }^{65,66}$ The $I_{50}$ values of the PN-A and $\mathrm{PN}-\mathrm{B}$ samples were higher than those of PROP (300 and $290 \mu \mathrm{g} / \mathrm{mL}$, respectively) and similar to those of Populus tremula and P. nigra (337 and $485 \mu \mathrm{g} / \mathrm{mL}$, respectively). ${ }^{67}$ Irrespective of the nature of the sample, the DPPH antioxidant activity increased during the first hour of the treatment, reaching the lowest $\mathrm{IC}_{50}$ value $(35 \mu \mathrm{g} /$ $\mathrm{mL}$ ) in the case of PROP (Table 4, entry 2). For a longer reaction time, a progressive increase in the $\mathrm{IC}_{50}$ values was observed (Table 4, entries 3 and 4).

To have a more realistic scenario of the complex interactions within the cell in biological systems, the PROP and the more $\mathrm{DPPH}$-active PN-A samples were selected for the evaluation of the antioxidant activity in Chinese hamster ovary $(\mathrm{CHO})$ cell line. Mammalian cells are endowed with several levels of defense mechanisms against oxidative damage, the first of which is based on the quenching of reactive oxygen species by antioxidants, such as ferritin and ceruloplasmin. ${ }^{68}$ The antioxidant activity was assessed by the ability to reduce the extent of DNA breakage [single-strand breaks (SSBs)] induced by tert-butyl-hydroperoxide ( $t$-butyl-OOH), using a slightly modified version of the alkaline comet assay, which is a rapid and sensitive procedure to quantify DNA lesions in mammalian cells. ${ }^{69,70}$ The frequency of SSBs of DNA and "alkali-labile sites" was measured immediately after the treatment and at different recovery times in $\mathrm{CHO}$, with and without pretreatment with the samples. This technique detects both SSBs and the so-called alkali-labile sites, which are observed as SSBs after denaturation under alkaline condition (both types of lesions will be referred to as SSBs because real SSBs and alkali-labile sites in this assay cannot be distinguished). The results obtained in control cells and in cells pretreated with the 
Scheme 1. Oxidation Products Detected during the Treatment of PROP, PN-A, and PN-B Samples with T. versicolor and TEMPO

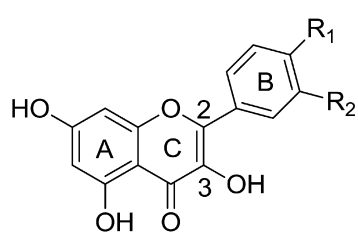<smiles>[R]c1ccc(C(=O)C2Oc3cc(O)cc(O)c3C2=O)cc1[R]</smiles>

Galangin: $\mathrm{R}_{1}=\mathrm{R}_{2}=\mathrm{H}$ Kaempferol: $\mathrm{R}_{1}=\mathrm{OH} ; \mathrm{R}_{2}=\mathrm{H}$ 1: $\mathrm{R}_{1}=\mathrm{OH} ; \mathrm{R}_{2}=\mathrm{H}$ Quercetin: $\mathrm{R}_{1}=\mathrm{R}_{2}=\mathrm{OH}$

2: $\mathrm{R}_{1}=\mathrm{R}_{2}=\mathrm{OH}$<smiles>O=C1C(=O)C(Oc2c(-c3ccccc3)oc3cc(O)cc(O)c3c2=O)(c2ccccc2)Oc2cc(O)cc(O)c21</smiles><smiles>Oc1cc(Cl)cc(O)c1O</smiles><smiles>Oc1ccc(O)cc1</smiles><smiles>Oc1ccccc1O</smiles>

Table 4. IC $_{50}$ Values of PROP, PN-A, and PN-B Samples before and after Treatment with Laccase from $T$. versicolor and TEMPO

\begin{tabular}{ccrrr} 
& & \multicolumn{3}{c}{$\mathrm{IC}_{50} a, b$} \\
\cline { 3 - 5 } entry & reaction time $(\mathrm{h})$ & \multicolumn{1}{c}{ PN-A } & \multicolumn{1}{c}{ PN-B } & \multicolumn{1}{c}{ PROP } \\
\hline 1 & 0 & $300 \pm 0.13$ & $290 \pm 0.16$ & $110 \pm 0.12$ \\
2 & 1 & $50 \pm 0.09$ & $53 \pm 0.07$ & $35 \pm 0.07$ \\
3 & 7 & $314 \pm 0.18$ & $251 \pm 0.27$ & $99 \pm 0.10$ \\
4 & 15 & $456 \pm 0.21$ & $339 \pm 0.12$ & $294 \pm 0.24$
\end{tabular}

${ }^{a} \mathrm{IC}_{50}$ is defined as the drug concentration $(\mu \mathrm{g} / \mathrm{mL})$ causing $50 \%$ inhibition of the desired activity. ${ }^{b}$ Each experiment was performed in triplicate.

samples after treatment with $t$-butyl-OOH are reported in Figures 2 and 3. Pretreatment with the samples alone did not increase the TM values (i.e., the product of the tail length and the fraction of total DNA in the tail), suggesting the absence of pro-oxidant activity in the samples after the laccase treatment, whereas the presence of $t$-butyl-OOH significantly enhanced the frequencies of SSBs, as shown by the increase of TM. The kinetics of the repair of the oxidative DNA damage was assessed at $0,0.5$, and $1 \mathrm{~h}$ after treatment with $t$-butyl-OOH (with or without pretreatment with the selected samples). We observed a statistically significant reduction in the mean TM in the presence of PROP with respect to $t$-butyl-OOH, except for the sample treated at $15 \mathrm{~h}$. In particular, the most effective compound in reducing the $t$-butyl-OOH-induced DNA damage was PROP after $7 \mathrm{~h}$ of treatment with laccase (Figure 2).

In a similar way, we observed a statistically significant reduction in the mean $\mathrm{TM}$ in the presence of $\mathrm{PN}$-A treated with laccase for short time compared with $t$-butyl-OOH alone. In this latter case, the most effective compound in reducing the $t$-butyl-OOH-induced DNA damage was the PN-A sample after $1 \mathrm{~h}$ of treatment (Figure 3 ).

\section{CONCLUSIONS}

In conclusion, polyphenols decreased during the treatment of propolis and poplar bud exudates with laccase from T. versicolor

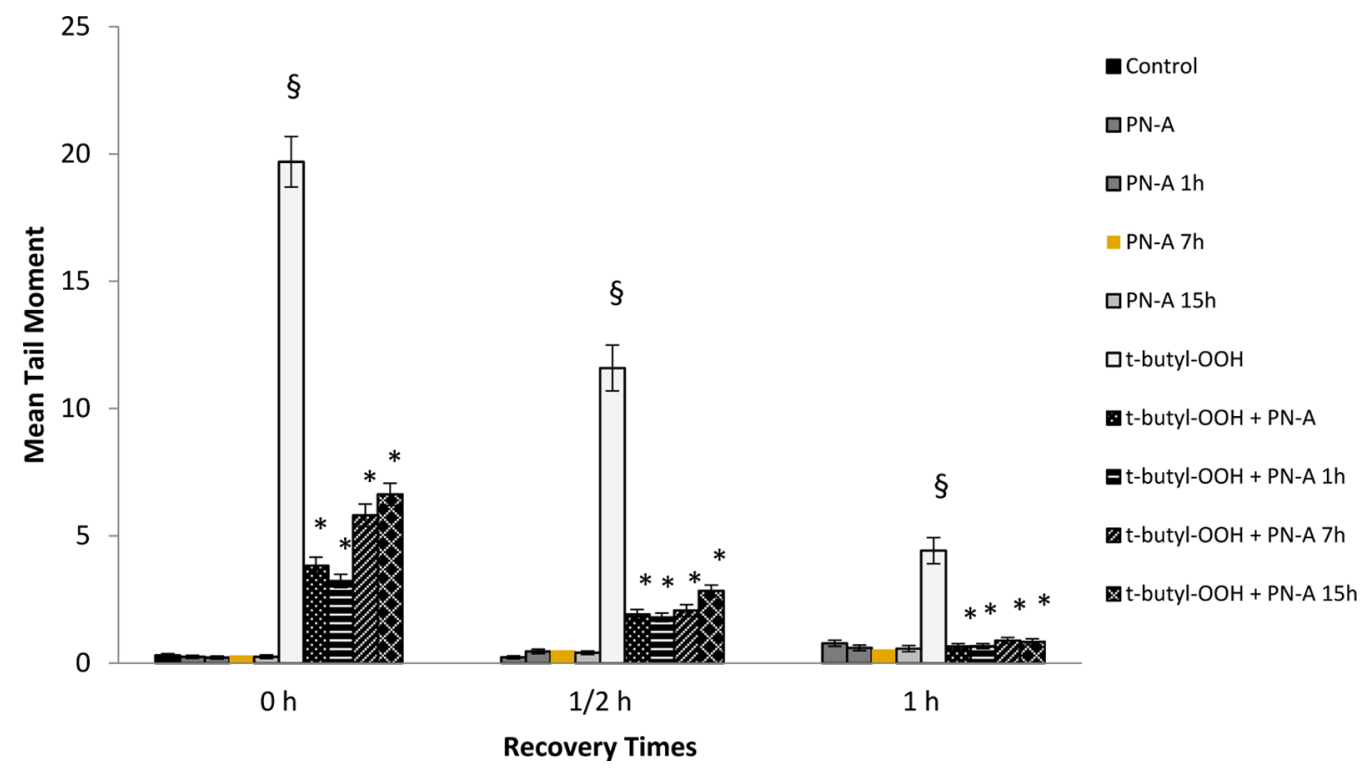

Figure 3. Mean TM values obtained at different recovery times for both control and $t$-butyl-OOH-treated samples with and without pretreatment with PN-A. Student's $t$-test, $\S t$-butyl-OOH vs control, $p<0.01$; $*$ PN-A 1,7 , and 15 h vs $t$-butyl-OOH, $p<0.01$. 
and TEMPO. Phenyl propanoid acids and flavonoids (with the only exception of recalcitrant flavones) were efficiently oxidized. Low-molecular-weight phenols hydroquinone, catechol, and phloroglucinol were produced as degradation products during the first period of the oxidation, in addition to some flavonol derivatives modified on the C-ring. ${ }^{71}$ The antioxidant activities of propolis and poplar bud exudates did not display a reactivity-related similarity to the trend of polyphenol derivatives. The antioxidant activity increased immediately (from 0 to $7 \mathrm{~h}$ ) and then decreased rapidly for higher reaction times. In the mammalian cells (comet assay), $t$ butyl-OOH markedly induced primary damage, whereas pretreatments with propolis and poplar bud exudates did not have effects on the DNA integrity, indicating the absence of pro-oxidant effects. The comet assay data clearly indicated that the samples treated with laccase and TEMPO were able to enhance significantly the extent and the rate of DNA repair of $t$ butyl-OOH-induced lesions. A marked protection against the oxidative DNA breakage was observed for PN-A (treatment at $1 \mathrm{~h}$ ) and PROP (treatment at $7 \mathrm{~h}$ ). On the basis of these data, the enhancement of the antioxidant properties of propolis and poplar bud exudates after treatment with laccase and TEMPO could be reasonably attributed to the formation of hydroquinone, catechol, and phloroglucinol because of their ability to scavenge radical species, ${ }^{72-73}$ even if a general modulatory effect on the endogenous antioxidant systems of the cell cannot be completely ruled out. ${ }^{76}$ Noteworthy, the PROP sample showed the highest antioxidant activity in the DPPH test, whereas PN-A was most effective in the comet assay, confirming a different responsiveness of the mammalian cells with respect to the DPPH analysis.

\section{EXPERIMENTAL SECTION}

Laccase from $T$. versicolor (Sigma-Aldrich) is a monomer, organized in three sequentially arranged domains with a molecular mass of approximately $62-70 \mathrm{kDa}$, having dimensions of about $6.5 \mathrm{~nm} \times 5.5 \mathrm{~nm} \times 4.5 \mathrm{~nm}$ and isoelectric point of 4,2. ${ }^{77,78}$ TEMPO, tert-butyl-hydroperoxide ( $t$-butyl$\mathrm{OOH}$ ) [75-91-2], and organic solvents were purchased from Sigma-Aldrich. Commercially available black bud poplar exudates ( $P$. nigra) and propolis were obtained from Shaanxi Teng Yun Biotechnology Co. Ltd (Lianhu District, Xian, China). All spectrophotometric measurements were made with a Varian Cary 50 UV-vis spectrophotometer equipped with a single-cell Peltier thermostated cell holder. Spectrophotometric data were analyzed with Cary UV software. All experiments were carried out in triplicate. GC-MS analysis was performed using a combined LC-GC-MS instrument by Varian. The following are the parameters used for the analysis: SLB-5ms capillary GC column; film thickness, $30 \mathrm{~m} \times 0.25 \mathrm{~mm} \times 0.25$ $\mathrm{mm}$ (Supelco-28471-U); flow velocity of the carrier (helium), $1.0 \mathrm{~mL} \mathrm{~min}^{-1}$; column gradient temperature, $140{ }^{\circ} \mathrm{C}(2 \mathrm{~min})$ to $300{ }^{\circ} \mathrm{C}(5 \mathrm{~min})$ at the rate of $5.0{ }^{\circ} \mathrm{C} \mathrm{min}{ }^{-1}$; and injection temperature, $250{ }^{\circ} \mathrm{C}$. The analysis was performed using an electron impact ion source $(70 \mathrm{eV})$ and interface (transfer-line temperature) of $250{ }^{\circ} \mathrm{C}$. The MS Data Review software was applied for the remote control of the instrument. The HPLC analyses were performed by Agilent 1260 Infinity II DAD Detector equipped with a Capcell Pak C18 column. The NMR spectra were recorded on a Bruker $400 \mathrm{MHz}$ spectrophotometer.

Preparation of Propolis and Poplar Samples. Raw propolis and poplar (10 g) were manually ground, pretreated with petroleum ether to remove resins $\left(600 \mathrm{~mL}, 6 \mathrm{~h}\right.$ at $\left.45^{\circ} \mathrm{C}\right)$, and extracted in Soxhlet with $\mathrm{MeOH}(80 \% \mathrm{v} / \mathrm{v}$ water) or EtOH $(80 \% \mathrm{v} / \mathrm{v}$ water) at reflux temperature for $48 \mathrm{~h}$. The obtained macerate was removed by filtration, and the solid portion was discarded. The recovered extract was distilled under reduced pressure $(650 \mathrm{mmHg}, 80 \mathrm{rpm})$ to yield PROP and PN-A/PN-B samples. For the GC-MS analysis, the appropriate sample (10 $\mathrm{mg}$ ) was treated with $300 \mu \mathrm{L}$ of NBSA (stabilized with $1 \%$ trimethylchlorosilane) in $100 \mu \mathrm{L}$ of pyridine, in the presence of oleic acid as internal standard at $90{ }^{\circ} \mathrm{C}$ for $2 \mathrm{~h}$.

Treatment of Propolis and Poplar Samples with Laccase from T. versicolor and TEMPO. The activity of laccase from $T$. versicolor was determined spectrophotometrically using 2,2'-azino-bis(3-ethylbenzthiazoline-6-sulfonic acid (ABTS) as a substrate. Briefly, ABTS $(300 \mu \mathrm{L}, 5 \mathrm{mM})$ and sodium acetate buffer $(0.1 \mathrm{M}, \mathrm{pH} 5,2.6 \mathrm{~mL})$ were incubated under vigorous stirring at $40{ }^{\circ} \mathrm{C}$ for $10 \mathrm{~min}$. Then, an appropriate amount of laccase in the sodium acetate buffer (100 $\mu \mathrm{L}$ ) was added to the mixture and the initial rate was immediately measured with an increase in the optical density at $436 \mathrm{~nm}$. One activity unit (U) is defined as the amount of enzyme that oxidized $1.0 \mu \mathrm{L}$ of ABTS per minute. The kinetic parameters $\left(K_{\mathrm{m}}, V_{\max }, V_{\max } / K_{\mathrm{m}}\right)$ were determined by measuring the enzyme activity at different concentrations of ABTS (0.1-5 $\mathrm{mM}$ ) and plotting the data in a double-reciprocal LineweaverBurk plot. The reaction was carried out by the same procedure as for the activity assay, using laccase $(0.1 \mu \mathrm{g})$ and measuring the absorbance at $436 \mathrm{~nm}$, as described above. ${ }^{79}$ The appropriate sample $(1.0 \mathrm{~g})$ and TEMPO $(6 \mathrm{mM})$ were treated with laccase $(100 \mathrm{U})$ in $0.1 \mathrm{M}$ sodium acetate buffer $(10 \mathrm{~mL}$, $\mathrm{pH}$ 5-5.5) in the presence of a low amount of organic solvent $\mathrm{CH}_{2} \mathrm{Cl}_{2}(5.0 \% \mathrm{v} / \mathrm{v})$. The amount of TEMPO was selected on the basis of data recently reported on the use of the LMS for the oxidation of recalcitrant aldehydes. ${ }^{31}$ At defined reaction times $(1,7$, and $15 \mathrm{~h})$, the reaction was extracted with ethyl acetate $($ EtOAc $)(30 \mathrm{~mL} \times 2)$. The organic layers were treated with a saturated solution of $\mathrm{NaCl}$, dried over anhydrous $\mathrm{Na}_{2} \mathrm{SO}_{4}$, and then filtered and concentrated under vacuum to yield the crude to be analyzed, as previously reported for parent substrates.

In the case of the reactions quenched at $7 \mathrm{~h}$, the crude was purified by HPLC using a procedure previously reported for the isolation of flavonol derivatives, with some modifications. ${ }^{80}$ The operating conditions were as follows: $\mathrm{MeCN} / \mathrm{H}_{2} \mathrm{O}$ (30\%) containing $0.1 \%$ trifluoroacetic acid; flow rate, $0.8 \mathrm{~mL} / \mathrm{min}$; and UV detection at $254 \mathrm{~nm}$. The retention times of compounds 1-3 were identified by co-injection with standard compounds. $^{54}$ NMR data of compounds $\mathbf{1 - 3}$ were consistent with those reported previously. ${ }^{80}$

2-(4-Hydroxybenzoyl)-2,4,6-trihydroxy-3(2H)-benzofuranone 1: $\mathrm{m} / z 446$ (detected as dimethyl silyl ether derivative); HRMS $[E I]^{-}: m / z$ calcd for $\mathrm{C}_{15} \mathrm{H}_{7} \mathrm{O}_{6} 283.0243[\mathrm{M}-\mathrm{H}]^{-}$, found 283.0246. ${ }^{1} \mathrm{H}$ NMR [dimethylsulfoxide (DMSO) $-d_{6}, 400$ $\mathrm{MHz}]: 5.86(\mathrm{~m}, 1 \mathrm{H}, \mathrm{H}-6), 5.92(\mathrm{~m}, 1 \mathrm{H}, \mathrm{H}-8), 6.80$ (d, J = 6.7 $\mathrm{Hz}, 2 \mathrm{H}, \mathrm{H}-3^{\prime}$ and $\left.\mathrm{H}-5^{\prime}\right), 7.57$ (d, $J=6.7 \mathrm{~Hz}, 2 \mathrm{H}, \mathrm{H}-2^{\prime}$ and $\mathrm{H}-$ $\left.6^{\prime}\right), 9.39(\mathrm{~s}, 1 \mathrm{H}, \mathrm{OH}), 9.96(\mathrm{~s}, 1 \mathrm{H}, \mathrm{OH}), 10.77(\mathrm{~s}, 1 \mathrm{H}, \mathrm{OH})$. ${ }^{13} \mathrm{C}$ NMR (DMSO-d, $\left.125 \mathrm{MHz}\right): 90.41(\mathrm{CH}), 95.84(\mathrm{CH})$, $103.76(\mathrm{C}), 105.51(\mathrm{C}), 115.80(\mathrm{CH}), 125.28(\mathrm{CH}), 127.39$ (C), 142.93 (C), 161.27 (CH), 166.31 (C), 173.85 (C), 190.47 (CO), 191.83 (CO).

2-(3,4-Dihydroxybenzoyl)-2,4,6-trihydroxy-3(2H)-benzofuranone 2: HRMS [EI] $]^{-}: m / z$ calcd for $\mathrm{C}_{15} \mathrm{H}_{6} \mathrm{O}_{7} 298.0114[\mathrm{M}-$ $\mathrm{H}]^{-}$, found 298.0118; ${ }^{1} \mathrm{H}$ NMR (DMSO- $d_{6}, 400 \mathrm{MHz}$ ): 5.87 
(m, 1H, H-6), 5.93 (m, 1H, H-8), 6.77 (m, 1H, H-5'), 7.50$7.55\left(\mathrm{~m}, 2 \mathrm{H}, \mathrm{H}-2^{\prime}\right.$ and $\left.\mathrm{H}-6^{\prime}\right), 9.37(\mathrm{~s}, 1 \mathrm{H}, \mathrm{OH}), 9.97(\mathrm{~s}, 1 \mathrm{H}$, $\mathrm{OH}), 10.72(\mathrm{~s}, 1 \mathrm{H}, \mathrm{OH}), 10.80(\mathrm{~s}, 1 \mathrm{H}, \mathrm{OH}),{ }^{13} \mathrm{C} \mathrm{NMR}$ (DMSO-d $6125 \mathrm{MHz}$ ): $90.33(\mathrm{CH}), 96.54(\mathrm{CH}), 100.46(\mathrm{C})$, $104.57(\mathrm{C}), 114.89(\mathrm{CH}), 117.33(\mathrm{C}), 123.82(\mathrm{CH}), 124.99$ (C), 144.73 (C), 151.36 (C), $158.53(\mathrm{CH}), 168.46$ (C), 171.86 (C), 189.87 (CO), 190.24 (CO).

Galangin dimer 3: HRMS [EI] $]^{-}: m / z$ calcd for $\mathrm{C}_{30} \mathrm{H}_{14} \mathrm{O}_{10}$ $534.0587[\mathrm{M}-\mathrm{H}]^{-}$, found 534.0582; ${ }^{1} \mathrm{H}$ NMR (DMSO-d $d_{6}$, $400 \mathrm{MHz}): 5.79$ (m, 1H, H-6"), 5.86 (m, 1H, H-6), 5.90-5.93 (m, 2H, H-8-H" ), 6.74-6.81 (m, 4H, H-3', H-5', H-3"', and $\mathrm{H}-$ $\left.5^{\prime \prime \prime}\right), 7.23-7.32\left(\mathrm{~m}, 2 \mathrm{H}, \mathrm{H}-3^{\prime}\right.$ and $\left.\mathrm{H}-3^{\prime \prime \prime}\right), 7.38$ (m, 2H, H-2' and $\left.\mathrm{H}-6^{\prime}\right), 7.49$ (m, 2H, H-2"' and H-6"' $), 8.32$ (s, 1H, OH), 8.99 (s, 1H, OH), $9.84(\mathrm{~s}, 1 \mathrm{H}, \mathrm{OH}), 10.61(\mathrm{~s}, 1 \mathrm{H}, \mathrm{OH}) .{ }^{13} \mathrm{C}$ NMR (DMSO- $\left.d_{6}, 125 \mathrm{MHz}\right)$ : $93.01(\mathrm{CH}), 94.19(\mathrm{CH}), 95.43$ $(\mathrm{CH}), 97.84(\mathrm{CH}), 102.66(\mathrm{C}), 104.50(\mathrm{C}), 125.81(\mathrm{CH})$, $126.28(\mathrm{CH}), 126.67(\mathrm{CH}), 127.89(\mathrm{CH}), 128.21(\mathrm{CH})$, 129.45 (CH), 130.19 (C), 130.79 (C), 133.53 (C), 136.48 (C), 157.88 (C), 158.80 (C), 161.08 (C), 162.27 (C), 163.91 (C), 166.31 (C), 166.74 (C), 178.45 (CO), 190.72 (CO), 196.53 (CO).

Antioxidant Activities of PROP, PN-A, and PN-B Samples as Evaluated by the DPPH Method. The quantitative assessment of the antioxidant activity of propolis and poplar samples was performed with a slight modification of the procedures reported in the literature. ${ }^{81} \mathrm{EtOH}$ was used as blank. The inhibition of free radical DPPH by the samples was monitored by measuring the decrease in the absorbance of solutions with different concentrations. In particular, the sample at an initial concentration of $1.0 \mathrm{mg} \mathrm{mL}^{-1}$ was diluted with ethanol until it achieved final concentrations of 25.0, 15.0, 10.0, 5.0 , and $2.5 \mu \mathrm{g} \mathrm{mL}^{-1}$. Then, $1.0 \mathrm{~mL}$ of $0.3 \mathrm{mM} \mathrm{DPPH}$ in ethanol was added to $2.5 \mathrm{~mL}$ of the appropriate solution and they were left to react in dark at room temperature $\left(26^{\circ} \mathrm{C}\right)$ over $30 \mathrm{~min}$. The absorbance readings were then taken with a spectrophotometer at $518 \mathrm{~nm}$. To make the results more reliable, the measurements were performed on five different concentrations of the same sample and, for each concentration, three readings were taken. The antioxidant activity was expressed as the $\mathrm{IC}_{50}$ value. The results were expressed as the obtained values plus standard deviation (SD) of three independent experiments for each extract analyzed. The results were statistically processed through the GraphPad Prism 5.1 software. $^{82}$

Antioxidant Activities of PROP, PN-A, and PN-B Samples as Evaluated by the Comet Assay. $\mathrm{CHO}$ cell line was cultured in Ham's F10 medium with $10 \%$ fetal calf serum, 1\% glutamine (Lonza), and 1\% streptomycin and penicillin (Lonza) at $37{ }^{\circ} \mathrm{C}$ in a humified atmosphere of $95 \%$ air and $5 \% \mathrm{CO}_{2}$. Moreover, to eliminate variations due to culture conditions, control and treated cultures were maintained concurrently and the same batches of the culture medium and preparation methods of chemicals were used for each experiment. $t$-Butyl-OOH (tert-butyl peroxide) was diluted with distilled water at the appropriate treatment concentration and used freshly made. In particular, a dose of $500 \mu \mathrm{M}$ was used. The samples were dissolved in DMSO at a concentration of $500 \mu \mathrm{g} / \mathrm{mL}$. For the experiments, the stock solutions were diluted with DMSO at the appropriate treatment concentration of $100 \mu \mathrm{g} / \mathrm{mL}$ and used freshly made.

Cell Treatments with $t$-Butyl-OOH and Selected Compounds. Briefly, the cell lines were seeded at a density of $5 \times 10^{5}$ cells $/ \mathrm{mL}$ in Ham's F10 complete medium and pretreated with the selected compounds $(100 \mu \mathrm{g} / \mathrm{mL})$ for $3 \mathrm{~h}$ at $37{ }^{\circ} \mathrm{C}$. The cells were exposed to $t$-butyl-OOH for $1 \mathrm{~h}$, washed in phosphate-buffered saline (PBS) to remove the oxidative agent, and suspended again in Ham's F10 complete medium. The treated cells were used for the comet assay $(t=0$, $1 / 2$, and $1 \mathrm{~h}$ ). All of the doses used here were chosen on the basis of pilot experiments.

Single-Cell Gel Electrophoresis (SCGE) Analysis (Comet Assay). The standard alkaline ( $\mathrm{pH}>13$ ) SCGE, or comet assay, analysis was performed as described earlier under visible fluorescent light. ${ }^{83}$ After the treatment, the cells were collected and processed for the assay. In short, $20 \mu \mathrm{L}$ of the cell suspension $\left(5 \times 10^{5}\right.$ cells $)$ was mixed with $80 \mu \mathrm{L}$ of $0.75 \%$ lowmelting-point agarose in $\mathrm{PBS}$ at $37{ }^{\circ} \mathrm{C}$ and immediately pipetted onto a frosted glass microscope slide precoated with a layer of $1 \%$ normal-melting-point agarose, similarly prepared in PBS. Two slides for each experimental point were then incubated in a lysis solution $(2.5 \mathrm{M} \mathrm{NaCl}, 10 \mathrm{mM}$ Tris- $\mathrm{HCl}$, $100 \mathrm{mM}$ EDTA, $\mathrm{pH} 10$, with $1 \%$ Triton and $10 \%$ DMSO freshly added) for 1 day at $4{ }^{\circ} \mathrm{C}$. After lysis, the slides were placed on a horizontal electrophoresis unit containing fresh electrophoresis buffer (1 mM EDTA, $300 \mathrm{mM} \mathrm{NaOH}, \mathrm{pH} 13$ ) and incubated for $15 \mathrm{~min}$ to allow unwinding of DNA. Electrophoresis was then conducted for $20 \mathrm{~min}$ at $25 \mathrm{~V}, 300$ $\mathrm{mA}$, and $4{ }^{\circ} \mathrm{C}$. Subsequently, the slides were gently washed three times in a neutralization solution $(0.4 \mathrm{M}$ Tris $-\mathrm{HCl}, \mathrm{pH}$ 7.5) for $5 \mathrm{~min}$ and fixed in fresh $100 \%$ methanol for $3 \mathrm{~min}$. The slides were stained with $50 \mu \mathrm{L}$ of ethidium bromide $(20 \mu \mathrm{g} /$ $\mathrm{mL}$ ) and covered with a coverslip. The stained nucleoids were examined at $400 \times$ magnification with an automatic image analyzer (Comet Assay III; Perceptive Instruments, U.K.) connected to a fluorescence microscope (Axioskop 2; Zeiss). To evaluate the amount of DNA damage, computer-generated TM values and percentages of DNA damage were used. For each experimental point, 100 cells were scored from two slides, for a total of 200 cells. The significance of the induction of mean TM in the effect of the $t$-butyl-OOH treatment versus that in control samples and the effects of the oxidative agent under different experimental conditions (i.e., with and without propolis or PN-A) were analyzed by Student's $t$-test for paired samples $(p<0.01)$. The results are represented as the mean \pm standard error of repeated experiments.

\section{ASSOCIATED CONTENT}

\section{Supporting Information}

The Supporting Information is available free of charge on the ACS Publications website at DOI: 10.1021/acsomega.7b00294.

SI \#1: GC profiles of PN-A, PN-B, and PROP samples; SI \#2: mass-to-charge ratio $(\mathrm{m} / z)$ value and the abundance of peaks of identified polyphenols; SI \#3: mass-to-charge ratio fragmentation spectra of identified polyphenols; SI \#4: structures of polyphenols identified in PN-A, PN-B, and PROP samples (PDF)

\section{AUTHOR INFORMATION}

\section{Corresponding Authors}

*E-mail: meschini@unitus.it (R.M.).

*E-mail: saladino@unitus.it. Mobile: +39 3402779329 (R.S.). ORCID 웅

Raffaele Saladino: 0000-0002-4420-9063

Notes

The authors declare no competing financial interest. 


\section{ACKNOWLEDGMENTS}

The FILAS project "MIGLIORA" of Latium Region (Italy) and Aboca srl San Sepolcro (Arezzo, Italy) are acknowledged.

\section{REFERENCES}

(1) Osés, S. M.; Pascual-Maté, A.; Fernández-Muiño, M. A.; LópezDíaz, T. M.; Sancho, M. T. Food Chem. 2016, 196, 1215-1223.

(2) Sönmez, M. F.; Çilenk, K. T.; Karabulut, D.; Ünalmiş, S.; Deligönül, E.; Öztürk, I.; Kaymak, E. Biomed. Pharmacother. 2016, 79, 44-51.

(3) Ristivojević, P.; Trifković, J.; Andrić, F.; Milojković-Opsenica, D. Nat. Prod. Commun. 2015, 10, 1869-1876.

(4) Wilson, M. B.; Spivak, M.; Hegeman, A. D.; Rendahl, A.; Cohen, J. D. PLoS One 2013, 8, No. e77512.

(5) Golubkina, N. A.; Sheshnitsan, S. S.; Kapitalchuk, M. V.; Erdenotsogt, E. Ecol. Indic. 2016, 66, 452-457.

(6) Acikelli, A. H.; Gustmann, S.; Bardenheuer, W.; Klein, J.; Dembinski, U.; Kohl, B.; Yip, K. T.; Nazif, A.; Stoll, R.; Strumberg, D.; Diáz-Carballo, D. Int. J. Clin. Pharmacol. Ther. 2013, 51, 51-53.

(7) De Lima, G. G.; De Souza, R. O.; Bozzi, A. D.; Poplawska, M. A.; Devine, D. M.; Nugent, M. J. D. J. Pharm. Sci. 2016, 105, 1248-1257.

(8) Funakoshi-Tago, M.; Okamoto, K.; Izumi, R.; Tago, K.; Yanagisawa, K.; Narukawa, Y.; Kiuchi, F.; Kasahara, T.; Tamura, H. Int. Immunopharmacol. 2015, 25, 189-198.

(9) Bankova, V.; Galabov, A. S.; Antonova, D.; Vilhelmova, N.; Di Perri, B. Phytomedicine 2014, 21, 1432-1438.

(10) Jerković, I.; Marijanović, Z.; Kuś, P. M.; Tuberoso, C. I. G. Chem. Biodiversity 2016, 13, 210-218.

(11) Yang, S.; Zhou, Y.; Ye, J.; Fan, G.; Peng, L.; Pan, S. J. Sci. Food Agric. 2016, 96, 2136-2141.

(12) Talla, E.; Tamfu, A. N.; Gade, I. S.; Yanda, L.; Mbafor, J. T.; Laurent, S.; et al. Nat. Prod. Res. 2017, 31, 1379-1389.

(13) Socha, R.; Gałkowska, D.; Bugaj, M.; Juszczak, L. Nat. Prod. Res. 2015, 29, 416-422.

(14) Juszczak, L.; Gałkowska, D.; Ostrowska, M.; Socha, R. Nat. Prod. Res. 2016, 30, 1436-1439.

(15) Nina, N.; Quispe, C.; Jiménez-Aspee, F.; Theoduloz, C.; Giménez, A.; Schmeda-Hirschmann, G. J. Sci. Food Agric. 2016, 96, $2142-2153$.

(16) Wang, X.; Sankarapandian, K.; Cheng, Y.; Woo, S. O.; Kwon, H. W.; Perumalsamy, H.; Ahn, Y.-J. BMC Complementary Altern. Med. 2016, 16, No. 65 .

(17) Hong, S.; Liu, S. Food Chem. 2016, 197, 415-421.

(18) Jiang, W.-J.; Ishiuchi, K.; Furukawa, M.; Takamiya, T.; Kitanaka, S.; Iijima, H. Bioorg. Med. Chem. 2015, 23, 6922-6929.

(19) Gallardo, E.; Madrona, A.; Palma-Valdés, R.; Espartero, J. L.; Santiago, M. Life Sci. 2015, 134, 30-35.

(20) Guazzaroni, M.; Pasqualini, M.; Botta, G.; Saladino, R. ChemCatChem 2012, 4, 89-99.

(21) Bozzini, T.; Botta, G.; Delfino, M.; Onofri, S.; Saladino, R.; Amatore, D.; Sgarbanti, R.; Nencioni, L.; Palamara, A. T. Bioorg. Med. Chem. 2013, 21, 7699-7708.

(22) Riva, S. Trends Biotechnol. 2006, 24, 219-226.

(23) Mot, A. C.; Damian, G.; Sarbu, C.; Silaghi-Dumitrescu, R. Redox Rep. 2009, 14, 267-274.

(24) Di Gennaro, P.; Bargna, A.; Sello, G. Appl. Microbiol. Biotechnol. 2011, 90, 1817-1827.

(25) Mate, D. M.; Alcalde, M. Biotechnol. Adv. 2015, 33, 25-40.

(26) Martinez-Ortiz, J.; Flores, R.; Vazquez-Duhalt, R. Biosens. Bioelectron. 2011, 26, 2626-2631.

(27) Morozova, O. V.; Shumakovich, G. P.; Shleev, S. V.; Yaropolov, Y. I. Appl. Biochem. Microbiol. 2007, 43, 523-535.

(28) Monti, D.; Ottolina, G.; Carrea, G.; Riva, S. Chem. Rev. 2011, $111,4111-4140$.

(29) Guazzaroni, M.; Bozzini, T.; Saladino, R. ChemCatChem 2012, 4, 1987-1996.

(30) Golibev, V. A.; Kozlov, Y. N.; Petrov, A. N.; Purmal, A. P. In Bioactive Spin Labels; Zhdanov, R. I., Ed.; Springer, 1992; pp 119-140.
(31) Piccinino, D.; Delfino, M.; Botta, G.; Crucianelli, M.; Grossi, V.; Passacantando, M.; Antiochia, R.; Favero, G.; Saladino, R. Appl. Catal., A 2015, 499, 77-88.

(32) Galli, G.; Gentili, P. J. Phys. Org. Chem. 2004, 17, 973-977.

(33) Arends, I. W. C. E.; Li, Y.-X.; Ausan, R.; Sheldon, R. A. Tetrahedron 2006, 62, 6659-6665.

(34) Chakroun, H.; Bouaziz, M.; Yangui, T.; Blibech, I.; Dhouib, A.; Sayadi, S. J. Mol. Catal. B: Enzym. 2013, 87, 11-17.

(35) Crestini, C.; Melone, F.; Saladino, R. Bioorg. Med. Chem. 2011, 19, 5071-5078.

(36) Khomutov, S. M.; Shutov, A. A.; Chernikh, A. M.; Myasoedova, N. M.; Golovleva, L. A.; Donova, M. V. J. Mol. Catal. B: Enzym. 2016, 123, 47-52.

(37) Pourcel, L.; Routaboul, J.-M.; Cheynier, V.; Lepiniec, L.; Debeaujon, I. Trends Plant Sci. 2007, 12, 29-36.

(38) Verloop, A. J. W.; Gruppen, H.; Bisschop, R.; Vincken, J.-P. Food Chem. 2016, 196, 1197-1206.

(39) Sóti, V.; Jacquet, N.; Apers, S.; Richel, A.; Lenaerts, S.; Cornet, I. J. Chem. Technol. Biotechnol. 2016, 91, 1914-1922.

(40) Moț, A. C.; Coman, C.; Miron, C.; Damian, G.; Sarbu, C.; Silaghi-Dumitrescu, R. Food Chem. 2014, 143, 214-222.

(41) Kheirandish, F.; Delfan, B.; Mahmoudvand, H.; Moradi, N.; Ezatpour, B.; Ebrahimzadeh, F.; Rashidipour, M. Biomed. Pharmacother. 2016, 82, 208-215.

(42) Hofer, M.; Falk, M.; Komůrková, D.; Falková, I.; Bačíková, A.; Klejdus, B.; Pagáčová, E.; Štefančíková, L.; Weiterová, L.; Angelis, K. J.; Kozubek, S.; Dušek, L.; Galbavý, S. J. Med. Chem. 2016, 59, 30033017.

(43) Al-Sayed, E.; Tolba, M. F.; Karonen, M. Rec. Nat. Prod. 2016, $10,812-817$.

(44) Azadmehr, A.; Oghyanous, K. A.; Hajiaghaee, R.; Amirghofran, Z.; Azadbakht, M. Cell. Mol. Neurobiol. 2013, 33, 1135-1141.

(45) Xiao, Y. Z.; Tu, X. M.; Wang, J.; Zhang, M.; Cheng, Q.; Zeng, W. Y.; et al. Appl. Microbiol. Biotechnol. 2003, 60, 700-707.

(46) Golibev, V. A.; Kozlov, Y. N.; Petrov, A. N.; Purmal, A. P. In Bioactive Spin Labels; Zhdanov, R. I., Ed.; Springer: 1992; pp 119-140.

(47) Andreu, G.; Vidal, T. Bioresour. Technol. 2011, 102, 5932-5937.

(48) Strong, P. J.; Claus, H. Crit. Rev. Environ. Sci. Technol. 2011, 41, 373-434.

(49) Baiocco, P.; Barreca, A. N.; Fabbrini, M.; Galli, C.; Gentili, P. Org. Biomol. Chem. 2003, 1, 191-197.

(50) Botta, G.; Delfino, M.; Guazzaroni, M.; Crestini, C.; Onofri, S.; Saladino, R. ChemPlusChem 2013, 78, 325-330.

(51) Ricklefs, E.; Girhard, M.; Koschorreck, K.; Smit, M. S.; Urlacher, V. B. ChemCatChem 2015, 7, 1857-1864.

(52) Kim, S.; Moldes, D.; Cavaco-Paulo, A. Enzyme Microb. Technol. 2007, 40, 1788-1793.

(53) Camarero, S.; Ibarra, D.; Martínez, M. J.; Martínez, A. T. Appl. Environ. Microbiol. 2005, 71, 1775-1784.

(54) Ghidouche, S.; Es-Safi, N.-E.; Ducrot, P.-H. Tetrahedron Lett. 2008, 49, 619-623.

(55) Krishnamachari, V.; Levine, L. H.; Parè, P. W. J. Agric. Food Chem. 2002, 50, 4357-4363.

(56) Brown, S. B.; Rajananda, V.; Holroyd, J. A.; Evans, E. G. V. Biochem. J. 1982, 205, 239-244.

(57) Hvattum, E.; Stenstrom, Y.; Ekeberg, D. J. Mass Spectrom. 2004, $39,1570-1581$.

(58) Kubo, I.; Nihey, K.; Shimizu, K. Bioorg. Med. Chem. 2004, 12, $5343-5347$

(59) Pource, L.; Routaboul, J.-M.; Kerhoas, L.; Caboche, M.; Lepiniec, L. Plant Cell 2005, 17, 2966-2980.

(60) Rechner, A. R.; Smith, M. A.; Kuhnle, G.; Gibson, G. R.; Debnam, E. S.; Rice-Evans, C. A.; et al. Free Radical Biol. Med. 2004, $36,212-225$.

(61) Labib, S.; Erb, A.; Kraus, M.; Wickert, T.; Richling, E. Mol. Nutr. Food Res. 2004, 48, 326-332.

(62) Harborne, A. J. Phytochemical Methods. A Guide to Modern Techniques of Plant Analysis, 3rd ed.; Chapman \& Hall Thomson Science: London, 1988; pp 42-46. 
(63) Lu, Y. H.; Huang, J. H.; Li, Y. C.; et al. Food Chem. 2015, 183, 91-100.

(64) Brand-Williams, W.; Cuvelier, M. E.; Berset Lebensm-Wiss, C. U. LWT-Food Sci. Technol. 1995, 28, 25.

(65) de Mendonça, I. C. G.; Porto, I. C. C. M.; do Nascimento, T. G.; de Souza, N. S.; Oliveira, J. M. S.; Arruda, R. E. S.; Mousinho, K. C.; dos Santos, A. F.; Basílio-Júnior, I. D.; Parolia, A.; Barreto, F. S. BMC Complementary Altern. Med. 2015, 15, No. 357.

(66) Wang, X.; Sankarapandian, K.; Cheng, Y.; Woo, S. O.; Kwon, H. W.; Perumalsamy, H.; Ahn, Y.-J. BMC Complementary Altern. Med. 2016, 16, No. 65.

(67) Benedec, D.; Oniga, I.; Muresan, B.; Mot, A. C.; Damian, G.; Nistor, A.; Silaghi-Dumitrescu, R.; Hanganu, D.; Duma, M.; Vlase, L. J. Food Qual. 2014, 37, 259-267.

(68) Reviewed in: (a) Offord, E.; van Poppel, G.; Tyrrell, R. Free Radical Res. 2000, Suppl. 33, S5-S19. (b) Cadet, J.; Bourdat, A. G.; D'Ham, C.; Duarte, V.; Gasparutto, D.; Romieu, A.; Ravanat, J. L. Mutat. Res. 2000, 462, 121-128.

(69) Fairbairn, D. W.; Olive, P. L.; O’Neill, K. L. Mutat. Res. 1997, $388,33-44$.

(70) Berni, A.; Meschini, R.; Filippi, S.; Palitti, F.; De Amicis, A.; Chessa, L. Mutat. Res. 2008, 650, 165-174.

(71) Fowler, Z. L.; Baron, C. M.; Panepinto, J. C.; Koffas, M. A. G. Yeast 2011, 28, 181-188.

(72) Peng, X.; Li, L.; Wang, X.; Zhu, G.; Li, Z.; Qiu, M. Fitoterapia 2016, 111, 18-23.

(73) Guazzaroni, M.; Pasqualini, M.; Botta, G.; Saladino, R. Chem CatChem 2012, 4, 89-99.

(74) Li, G.-Q.; Zhang, Y.-B.; Wu, P.; Chen, N.-H.; Wu, Z.-N.; Yang, L.; Qiu, R.-X.; Wang, G.-C.; Li, Y.-L. J. Agric. Food Chem. 2015, 63, 10257-10262.

(75) Bozzini, T.; Botta, G.; Delfino, M.; Onofri, S.; Saladino, R.; Amatore, D.; Sgarbanti, R.; Nencioni, L.; Palamara, A. T. Bioorg. Med. Chem. 2013, 21, 7699-7708.

(76) Gau, J.; Furtmüller, P. G.; Obinger, C.; Prévost, M.; Van Antwerpen, P.; Arnhold, J.; Flemmig, J. Free Radical Biol. Med. 2016, 97, 307-319.

(77) Bautista, L. F.; Morales, G.; Sanz, R. Bioresour. Technol. 2010, 101, 8541-8548.

(78) Piontek, K.; Antorini, M.; Choinowsky, T. J. Biol. Chem. 2002, 277, 37663-37669.

(79) Lineweaver, H.; Burk, D. J. Am. Chem. Soc. 1934, 56, 658-661.

(80) Kubo, I.; Nihei, K.; Shimizu, K. Bioorg. Med. Chem. 2004, 12, $5343-5347$.

(81) Brand-Williams, W.; Cuvelier, M. E.; Berset, C. LWT-Food Sci. Technol. 1995, 28, 25-30.

(82) Che, Z.; Bertin, R.; Froldi, G. Food Chem. 2013, 138, 414-420.

(83) Tice, R. R.; Agurell, E.; Anderson, D.; Burlinson, B.; Hartmann, A.; Kobayashi, H.; Miyamae, Y.; Rojas, E.; Ryu, J. C.; Sasaki, Y. F. Environ. Mol. Mutagen. 2000, 3, 206-211. 